\title{
Nikola Danišová, Mariana Čechová, Prolegomena k pramotívu premeny (Prolegomena do pramotywu przemiany), Verbum Praha, 2019, ss.117.
}

Recenzowane dzieło - monografia naukowa - wpisuje się w sposób nowatorski i oryginalny w nurt szeroko rozumianej semiotyki, a konkretnie architekstualnej tematologii, która jest uprawiana na fakultecie filozoficznym UKF w Nitrze (M. Čechová, L'. Plesnik). Korzysta ona ze znanych już i usankcjonowanych w nauce takich dyscyplin, jak folklorystyka, antropologia kulturowa, psychologia głębi i semiotyka egzystencjalna. Wchodzi ona w nurt badawczy, który obejmuje mity, eposy, baśnie i legendy. Praca powstała w ramach projektu APVV-17-0026 i obejmuje swym zasięgiem praprzyczyny — archetypy, pojawiające się w otaczającej, zmiennej rzeczywistości znakowej.

W pierwszym rozdziale Marginalie $k$ pramotivu premeny (Marginalia do pramotywu przemiany) na plan pierwszy wybija się tutaj semantyczny, estetyczny i antropologiczny punkt widzenia, będący w konkretnej sytuacji głębokim wniknięciem metamorficznych motywów. W konsekwencji chodzi o stworzenie słownika tematologicznego, w którym ważną rolę odgrywa tekst. Już we wstępie pojawia się architekstualna tematologia. Gromadzi ona w sobie wspomniane powyżej dyscypliny, które w tematologicznym segmentowaniu obejmują: algorytmy, motywy, postawy i inne. Widoczne są one w mitach, eposach, baśniach i legendach.

Bardzo ważne są motywy ludowej transformacji jako jednego z archetypicznych przedstawień w kulturze różnych kontynentów (Europa, Azja, Ameryka, Afryka, Australia). Bazą materiałową są tutaj klasyczne narracje (mity, eposy, legendy, teksty religijne itp.) i ich wpływ w kulturowym lub religijnym kontekście na obrazowanie. Na ogół nie dają się one wprost identyfikować genologicznie. Wykorzystują one typowe znaki mitu z jednej strony, z drugiej zaś wyznaczają atrybuty, motywy i tematy. 
Autorki na szerokiej bazie tekstowej (między innymi materiały wietnamskie, indiańskie, mongolskie, czukockie, melanezyjskie, australijskie, kaukaskie, kazachskie, arabskie) wyprowadzają motyw transfiguracji. Transformacja (metamorfoza) jest to zmiana własności fenomenu (substancji). Temu procesowi podlega wszystko, co ożywione i nieożywione. Danišová i Čechová wprowadzają tutaj pojęcie ontogenetycznego i filogenetycznego rozwoju, co uwidacznia się choćby w psychologiczno-kognitywistycznym funkcjonowaniu organizmu. Substancjonalna przemiana to transformacyjny proces, którego temat doczesny albo każde podobieństwo spaja mitologiczno-magiczne myślenie.

Chodzi tu o uniwersalny, antropologiczny fenomen, który objawia się w do dziś znanych przejawach fikcjonalnych cywilizacyjno-kulturowych. Przemiana substancjonalna może $\mathrm{w}$ świecie aktualnym/realnym iść w parze z przemianami ontogenetycznymi (z biologiczno-fizykalnymi i w sposób specyficzny dla człowieka psychologiczno-kognitywistyczny), które są sprzężone z procesami/rytuałami inicjacji. Wszystkie to kwestie zawiera w sobie międzynarodowa klasyfikacja indeksowania Aarne - Thompson - Uther (ATU). Uwzględnia ona przemiany społeczne, przemiany cielesne i przemiany psychiczne (osobowe). Wszystkie te rozważania odwołują się do konkretnych badaczy, takich jak Arnold van Gennep, Nathorp Frey, Władimir Propp czy Abraham Maslow.

Archinarracje wyrażają rytuały przejścia (inicjacje) i rytualne nawiązania. Semiotyzują one społeczne oraz duchowe przejścia człowieka w określonej kulturze i od jednego etapu do kolejnego. Podczas tego adept otrzymuje prawa i powinności. Usunięty ze swojego socjalnego planu dostaje się do granicznej sfery, w której traci rodową i społeczną tożsamość. Przywrócić ją może tylko nowonarodzenie, czyli powrót do tradycyjnych wartości. Metodą oddziaływania staje się tutaj gradacja swój - obcy. Ten dualizm oznacza dwie sfery; w pierwszym przypadku — to, co bezpieczne, w drugim natomiast - tajemnicę, niebezpieczeństwo, a w konsekwencji swoisty mikrokosmos, w którym dochodzą do głosu bogowie i demony.

W drugiej części dzieła - Marginalia k pramotivu smrti (Marginalia do pramotywu śmierci) w marginaliach początku rozpatruje się śmierć jako czynnik fizyczno-biologiczny. Autorki zauważają, że aż do końca XIX stulecia była ona częstsza niż dzisiaj (epidemie, wyniszczające wojny itp.). W tekstach folklorystycznych śmierć jest motywem ekspozycyjnym, niekiedy perypetią lub rodzajem katastrofy. W ludowych fabułach objawia się przez personifikacje - charakterystyczny jest tutaj obraz śmierci-żony, która może dawać życie, ale może też zabrać. W korpusie europejskich archinarracji śmierć występuje jako „śmiercka”, kosiarzyca, byt demonologiczny, przewoźnik i w formach zoomorficznych (koza, pies). Wszystkie te warianty pojawiają się w dziełach braci Grimm. Na ich przykładzie Danišová i Čechová pokazują przeciwieństwo życia i śmierci, przy czym ta ostatnia przybiera różne kształty. Gruntowna analiza utworów obrazuje właśnie ich zmienność, która wypływa z motywów doby przedchrześcijańskiej, legend, starych przekazów ustnych i pisanych. Zaczynają się one już od baśni Hugona von Trimberga (1300), następnie w XVI i XVII wieku mamy inne utwory tego gatunku, w których pojawia się śmierć.

Utwory braci Grimm są zbudowane zazwyczaj na opozycji dobra i zła, życia i śmierci, biedy i bogactwa oraz płaszczyźnie ontologiczno-metafizycznej: Boga i diabła, Boga i Śmierci, Śmierci i śmiertelnika. Postacią specyficzną jest niewątpliwie macocha, która staje się nosicielką wszystkich złych cech. Praca Danišovej i Čechovej wpisuje się w aktualny nurt badawczy, który występuje w europejskiej tematologii. Dzięki wykorzystaniu interdyscyplinarnych metod efekt końcowy przynosi satysfakcjonujące rezultaty. Można powiedzieć, że autorki 
stanęły na wysokości zadania, a ich praca daje wymierne rezultaty, przede wszystkim dzięki umiejętności szerokiego spojrzenia na problem, wielości przywołań tekstowych (utwory praktycznie z całego świata) i próbie typologizacji, która opiera się na gruntownym aparacie krytycznym oraz wykorzystaniu dostępnych źródeł. Ostateczny efekt, choć niewielki objętościowo, jest znaczący. Co ważne, dzieło ma dwie części, które dokładnie do siebie przylegają. Pierwsza z nich analizuje motywy metamorficzne, w drugiej natomiast pokazuje się motyw śmierci przez odwołanie się do mitów, baśni, eposów i tekstów religijnych z różnych kultur świata. Nikola Danišová opracowała praktyczny aspekt dzieła, natomiast Mariana Čechová zajęła się stroną teoretyczną. Całość zasługuje na najwyższe uznanie i jest ze wszech miar wartościowa.

KRZYSZTOF BILIŃSKI

iD https://orcid.org/0000-0002-8679-4168 